International Journal of English Literature and Social Sciences
Vol-6, Issue-1; Jan-Feb, 2021
Journal Home Page Available: $\underline{\text { https://ijeab.com/ }}$ Journal DOI: $10.22161 /$ ijels

\title{
Neoliberal Restructuring in Philippine Education: Towards Performativity
}

\author{
Jessie Grace M. Sannadan, Pinky Larcelle D. Lang-ay
}

Kalinga State University, Tabuk City, Kalinga, Philippines

Received: 29 Oct 2020; Received in revised form: 29 Jan 2021; Accepted: 15 Feb 2021; Available online: 25 Feb 2021

(C)2021 The Author(s). Published by Infogain Publication. This is an open access article under the CC BY license

(https://creativecommons.org/licenses/by/4.0/).

\begin{abstract}
This research article focuses on the manifestations of neoliberalism in Philippine Education and its effect on performativity. Qualitative meta-analysis is used to conduct a rigorous secondary qualitative analysis of primary qualitative findings. Its purpose is to provide a more comprehensive description of a phenomenon and an assessment of neoliberalism's influence on the performativity of Philippine Education. The study determined that neoliberalism is manifested in the $K$ to 12 Program and the Quality Management Mechanisms in Philippine Higher Education. The study further concludes that 'performativity' is apparent in teachers' day-to-day activities and teachers' social relations. Teachers are required to choose and judge their actions. These actions, in turn, are judged by others based on their contribution to organizational performance. The stricter qualification standards measured through a minimum set of criteria evaluated by accrediting agencies are also set for Philippine Higher Education Institutions.
\end{abstract}

Keywords - Neoliberalism in Higher Education, Performativity, Philippines Education.

\section{INTRODUCTION}

Education has an essential function in the development of the state and its people. Its primary purpose serves as an instrument for national economic interest ${ }^{[1]}$. Thus, education, in all aspects, is one of the most important factors of development. Any state could attain sustainable economic growth through sufficient investment in human capital, specifically in education ${ }^{[2]}$. Public education is indeed a reliable venture of the government in most counties. Enormous social and economic benefits are guaranteed in this public expenditure. As contended, the greater the government invest in this sector, the lesser the citizens' probability of becoming liabilities of the state ${ }^{[3]}$. Thus, the state's investment in education is far more costeffective than paying for the social and economic concerns of under-funded, low-quality schools.

It is now identified that sufficient support and investment in education, particularly basic knowledge, offers a solid base for economic and social development in most developing countries. However, due to the persisting increase of enrolment, problems like low completion rates, expansion of school drop-outs, and poor student learning came to the fore ${ }^{[4]}$.

The 1987 Constitution also mandates that education must be allocated with the largest part of its wealth. The Department of Budget and Management has given six hundred seventy-two billion pesos to finance the Philippines' education sector for 2018. Provisions in the law are set to allocate this amount to enhanced quality education delivery to the Filipino people. Unluckily, corruption is deep-rooted on the education sector of the country. The fund in the education sector is indisputably one of the most susceptible sources of fraud. It is a widespread view that corruption is one of the significant challenges in the Philippines, and as aforementioned, the education sector is not an exception to it ${ }^{[5]}$. Corruption exists at various levels, including the Department of Education (DepEd) ${ }^{[6]}$. While DepEd is the Philippines' most immense bureaucracy, with over half a million people employed [6], it is considered one of the country's most corrupt national agencies ${ }^{[7]}$.

On the one hand, the Commission on Higher Education 
(CHEd), the chief agency tasked to supervise higher education institutions in the state, is not resistant to corruption. As part of the civic bureaucracy of the government, "it is at risk to the influence of political dynamics, which promotes corruption, especially at the implementation level, "elite capture," patronage politics, and a long-established culture of informal bureaucratic influence" ${ }^{[8]}$. This shows that corruption has been systematically institutionalized, and it has caused severe structural constraints for the country's improvement. It poses a challenge that necessitates more in-depth investigation and understanding into its roots and dynamics if one has to eliminate it from our system. Given the massive wealth gap and income between the rich and poor in a resource-depleted country like the Philippines, this has mainly been due to its neoliberal economic policies.

\section{CONCEPTUAL BACKGROUND}

\subsection{What is Neoliberalism?}

Neoliberalism was created by a German scholar named Alexander Rustow, which he described as the primary concern of the price mechanism, the free enterprise, the competition system, and a healthy and impartial State. It is called "neo" or new mainly because there was considerably old liberalism where neoliberalism has been entrenched. Liberalism by a Scottish economist named Adam Smith in his book Wealth of the Nations [9] advocated for the abolition of government interference on any matters regarding the state's economy. This means no restrictions on manufacturing, no barriers to commerce, no tariffs, and free trade was the best way to develop the nation. It was considered liberal as it takes to the sense of boundlessness.

This application of individualism motivated "free" enterprise," "free" competition -- which came to mean freedom for the capitalists to make vast profits as they wished ${ }^{[10]}$. Though with much resemblance, classical liberalism and neoliberalism are two different entities as one came from the other. By differentiating the two, one can fully understand how neoliberalism flourished and has widely been embraced by most countries' governments.

For classical liberalism, the power of the state is a negative notion. In classical liberalism, an individual is seen as autonomous from the dictates of the country. It points out the private individual must be freed absolutely from the "obstructive" powers. Having control of the government is nonetheless extremely unnecessary and thus creates a clash and is unacceptable for the government.

On the other hand, neoliberalism took the role of the government as "instrumental." Here, the state is the one that creates the market where its power to set conditions, rules, and interventions are considered necessary for its operation.

The government is one that creates an individual that is enterprising and competitive [11]. Therefore, the government does not impede neoliberalism's goals and is somewhat necessary and imperative. This shift of image of neoliberalism has become the reason why it took its splendor in many nations as it profits the government too, most especially the earning capitalists in the government.

\subsection{What is Performativity?}

Performativity is a technology, a culture, and a mode of regulation that employs judgments, comparisons, and displays as means of incentive, control, attrition, and change ${ }^{\wedge}$ based on rewards and sanctions (both material and symbolic). The performances (of individual subjects or organizations) serve as productivity or output measures, or displays of 'quality,' or 'moments' of promotion or inspection. As such, they stand for, encapsulate or represent the worth, quality, or value of an individual or organization within a judgment field. The issue of who controls the area of judgment is crucial.

The installation of the new culture of competitive performativity includes using a mixture of devolution, targets, and incentives to bring about new forms of sociality and new institutional forms. In education, such ideas' impact is evident in the myriad of 'institutional devolution' and 'site-based management' initiatives being introduced in public sector organizations around the world. These institutions are encouraged to make themselves different from one another, stand out, and 'improve' themselves. In effect, they are to take accountability for transforming themselves and disciplining themselves and their workers; in the same way 'employees are at the same time required, individually and collectively, to recognize and take responsibility for the association between the security of their service and their contribution to the competitiveness of the goods and services they produce' (Willmott 1993: 522). Organizational collaboration and older forms of collective relations among workers are replaced by performative competition.

Thus, the manager's work, the new hero of educational reform, includes integrating the attitude and culture within which workers feel responsible and, at the same time, dedicated or personally invested in the organization. In part at least beneficiaries of reform, these new managers are the 'technicians of transformation' (May 1994: 619) or what Foucault calls 'technicians of behavior,' their task 'to produce docile and capable bodies.' (Foucault 1979a: 294). In Bernsteinian words, these new invisible 
pedagogies of supervision, realized through appraisals, performance reviews, and forms of performance-related pay, 'open up' more of the managed to control. The weaker frames of new managerialism enable a more excellent range of the workers' behavior and emotional life to be made public (Bernstein 1971: 65).

\subsection{Neoliberal Restructuring in Education}

In the Philippines, Professor Jose Maria Sison ${ }^{[12]}$, the Chairperson of the International League of the People's Struggle, has also spoken about neoliberalism's ills. For him, the masses are suffering much from the terrible status of global depression where exploitation, impoverishment, oppression, and all kinds of abuse have been brought by the capitalists whose intention is to control the economy. In the Philippines, it is extensively observed how a few elites control the country's resources and businesses, allowing the rich to grow richer and the poor to grow poorer, worsening the gap between them. Neoliberalism exploits natural resources and people, most especially in less developed countries, like ours. It forces the redistribution of assets from the communal ownership to market enterprise and agonizes the public ${ }^{[13]}$.

Sison, in his article entitled APEC's Neoliberal Offensive and its effect on education ${ }^{[12]}$, argued that neoliberal school reforms led to the budget cut in government spending on education as it increases privatization. State universities, colleges, public schools, and even non-profit private schools are operated in massive collaboration with big businesses. This will directly distort the schools' objectivity when it comes to decision-making, as it may affect these businesses' interests. In the spirit of "utang na loob" or indebtedness, schools are now leaning towards distorted academic priorities and biased stance on social issues to please its benefactors. Most importantly, the current positions on new policies and reforms as "socially just" are just a façade. Instead, in honesty, they serve to reinforce capitalist society that sees teaching and learning as a means to reproduce inequities instead of regarding it as a high-caliber profession that can contribute to a more just, equitable, and democratic society ${ }^{[14]}$.

The curriculum and all other changes in the world's educational setting are revised to fit businesses' needs and feed factories with the workforce. Neoliberalism has geared towards establishing a new moral order of schools to produce the new students who are appropriate to and appropriated by the neoliberal economy ${ }^{[15]}$. Local universities are supposed to give the students better chances to compete globally by sending promising graduates to world-class universities and accepting international students. Yet, only a handful of them is given this opportunity. The bulk of schools are left as manufacturers of diplomas to oil the capitalist countries' skilled labor force.

\section{OBJECTIVES}

1.To determine the manifestations of neo-liberal restructuring in Philippine Education; and

2.To determine the effects of neoliberal restructuring on the performativity of Philippine Education.

\section{SIGNIFICANCE OF THE STUDY}

The study will be beneficial to policy makers and curriculum planners to improve the existing programs and policies in Philippine education.

\section{RESEARCH METHODOLOGY}

This study used a qualitative research design. Previous related studies and current information on neoliberalism, local, and international were examined using a content analysis approach. Interviews and observations were also conducted to gather an in-depth analysis of the study to gather data that will lead to the attainment of the objectives of the study: (1) to determine the manifestations of neoliberalism in Philippine Education and (2) to determine the effects of neoliberalism on the structure of Philippine Education.

This research's findings were obtained from qualitative interviews with 68 faculty members and 148 students from state universities and colleges in the region of Cordillera and the 46 graduates working overseas. Besides, I chose Bachelor of Arts in English (AB English), Bachelor of Secondary Education major in English (BSED English), and the Bachelor of Information Technology (BSIT) as the focus programs of the study. As claimed, the Philippines is fast becoming the world's low-cost English language teacher - with a speedy increase in overseas students coming to learn English or study in Englishspeaking universities. The desire for employability and future work drives the popularity of particular majors within Philippine higher education institutions. Yet college majors that experience the most sudden peaks in enrollment are often those that Filipinos associate with greater working overseas (Jimenez-David 2008). While there were majors related to local demands in the Philippine labor market (e.g., accounting and criminology), the most prominent enrolment peaks came with majors linked to jobs overseas. As teachers in the College of Liberal Arts and College of Education in a state university for many years, it was observed that many of our graduates from the three programs are employed 
overseas as English teachers and Computer programmers; this can be justified by the annual tracer studies and employability studies conducted. We sought permission by sending letters to conduct interviews among the state universities and colleges in the Cordillera Region among the faculty members and students. At the same time, we could reach our overseas participants through Facebook messenger, e-mails, and video calls. These interviews provided first-hand information on how Philippine universities attempted to anticipate and adjust to predicted labor demands overseas, and how these efforts implicated faculty and students. We asked instructors how they thought about their role in preparing students for overseas jobs, what they consider the challenges of their work, and how they negotiate school owners and students' expectations. In student interviews, we asked participants how they chose their college majors, their struggles in the program, and their thoughts about future job prospects.

\section{RESULTS AND DISCUSSION}

\section{Manifestations of Neoliberalism in Philippine Education}

The K-12 Program

A. The Implementation of the K-12 Program in Basic

\section{Education}

Since the Enhanced Basic Education Act or the K-12 Law was approved, the Philippines has finally embarked on its most innovative change to the schooling system in decades, the K-12 reform.

K-12 extends compulsory education to grades 11 and $12^{[16]}$, adding two years to secondary school and making secondary education mandatory. Before its implementation, the Philippines was the only country in Asia, and one of only a few in the world, to have a basic education system of just ten years. The EBEA also directed kindergarten as the start of required formal schooling, while the Kindergarten Act of 2012 made preschool at no cost. In August 2016, 1.5m Filipino students attended 11th grade, with senior school students decide between four tracks through the system: academic, technical-vocational, sports, or the arts. Much of the initiative's resistance triggered five separate petitions to the Supreme Court, centered on whether the country's teachers, schools, and administration could implement the reform. President Duterte expressed skepticism about the program before he was elected, but changed his mind in May 2016 after DepEd's delegation told him that the change was necessary. Filipino students were falling behind their neighbors.

Indeed, increased spending on primary education
- including an expanded Alternative Learning System (ALS) - is a centerpiece of the new president's 10-point socioeconomic program. President Duterte insists that the Philippines' human capital's growth is the primary concern of his administration. Building on existing programs, the education secretary, Leonor Briones, said that the Duterte administration's education policy intends to ensure that the country provides a quality education accessible to all and relevant to the nation's needs. Filipinos should also find education "truly liberating" by developing critical thinking skills and appreciating the arts' culture.

Conversely, Sison (2015) [12] argued that implementing the program mentioned above in primary education is deemed an illustration of neoliberal school reform. It may seem like a "catch up with globalization" as what the state is merely trying to portray, a more genuine reason behind it could mean to be able to produce more capable workers that can compete with underdeveloped nations in the quest to make a higher reserve of the skilled labor force to the world market and to keep down wages in Asia Pacific mainly. The last two years of K-12 focuses on specialized and technical skills, as such example seen on the so-called Technology and Livelihood Education (TLE), where students undergo learning modules like house-keeping, plumbing, welding, caregiving, carpentry, cosmetology, pastry, among others [17].

In support of this contention, core countries (San Juan, 2013a) ${ }^{[18]}$ and big corporations ${ }^{[19]}$ are very supportive of $\mathrm{K}$ to 12 . Official documents from the Australian Department of Foreign Affairs and Trade (2013), the national office of the Department of Education ${ }^{[20]}$, and the Department of Education Regional Office VI (2013) highlighted the significant role of the Australianlisted firm Cardno in the management and implementation of $\mathrm{K}$ to 12 in the Philippines, on top of the Australian Agency for International Development's (AusAID) participation as one the scheme's financiers. The United States Agency for International Development (USAID), Asian Development Bank, and the World Bank also offer K to 12 (San Juan, 2015). As early as 2010, the Business Processing Association of the Philippines (BPAP), Chamber of Commerce of the Philippine Islands (CCPI), Employers' Confederation of the Philippines (ECOP), Makati Business Club (MBC), Philippine Business for Education (PBS), Philippine Chamber of Commerce and Industry (PCCI), Semiconductor and Electronics Industries of the Philippines (SEIPI), and the Joint Foreign Chambers of the Philippines, consisting of American Chamber of Commerce of the Philippines, Australian-New Zealand Chamber of Commerce, Canadian Chamber of Commerce of the Philippines, European Chamber of Commerce of the 
Philippines, Japanese Chamber of Commerce and Industry of the Philippines, Korean Chamber of Commerce of the Philippines, and Philippine Association of Multinational Companies Regional Headquarters signed a Memorandum of Agreement (MOA) with the Department of Education (DepEd), in support of $\mathrm{K}$ to $12^{\text {[21]. }}$

This new educational reform can accurately provide notable advantages to these core countries and big corporations. It can serve as a solution to their declining profit rates worsened by an unimpressive global trade growth rate. Since developed countries have comparatively higher wage rates and more vital labor unions ${ }^{[22]}$, workers cannot merely accept below-average wages typical in developing countries. Consequently, due to the extreme demand for highly-skilled workers, the capitalist is more than thrilled to employ migrant workers from developing countries (trained under the $\mathrm{K}$ to 12 program), who accept lesser wage rates than citizens from the urbanized nations.

\section{B. Restructured Curriculum}

Another manifestation of Philippine education's neoliberal restructuring is eliminating required courses in the core curriculum to give space for more technicalrelated times. Essential subjects in Humanities and Social Science, formerly compulsory, were removed in the senior high school/junior college level. Integral to critical pedagogy — such as Philippine History-where Filipino students have the chance to free their minds from what Renato Constantino ${ }^{[23]}$ branded as "miseducation" wrought by centuries of colonial regulation, and therefore realized that learning history is imperative "...to synthesize the experience of the past, to obtain a concrete vision of the future" [24] towards the full liberation of society's marginalized or exploited; Filipino - the national language which is also the language of societal activities in the state [25]; Literature - a prominent venue for Freireianconscientization, as Philippine literature has a strong socially conscious/realist tradition [26]; and Philippine Government \& Constitution (a course focusing on the constitutional rights and duties of citizens) - have been either abolished in junior high school, not incorporated in senior high school or wiped out in the college curriculum.

In summary, to increase their competitiveness and productivity, colleges and universities focus on the more profitable programs and trim off those percieved marginal or critical (such as Humanities). They commercialized their lands, buildings, research outputs, and other knowledge resources. They cram more courses into a year and shift to trimesters to produce graduates at a quicker rate.

High school and college education have been condensed to the mere learning of technical skills for instant employment, as the $\mathrm{K}$ to 12 scheme aim to "...form a new generation of children who will not have the ability to think or create or listen... " as Mr. Glenn Holland, a music teacher in the movie Mr. Holland's Opus ${ }^{[27]}$ spoken in caution against the death of General Education/Liberal Arts subjects in the USA.

\section{Training Specialized Skills for Export}

In 1974, former president Ferdinand Marcos institutionalized outmigration in the Philippines, which made the country gained prominence as a migrant-sending nation. The government took the responsibility of certifying migrants' exit papers and qualifications, ensuring their safety, and brokering their labor to potential employers ${ }^{[28]}$. While previously perceived as a provisional measure to address unemployment, succeeding administrations sustained this labor export policy, recognizing that Filipino workers' remittances substantially impacted their economies. The current local economic crisis and political instability have also influenced many Filipinos to pursue employment overseas, increasing migrants' outflow. Due to the country's ability to use outmigration as a prospect for development, the Philippines gained praises from international policymakers, making its migration policies a model for other migrant-sending nations ${ }^{[29]}$.

The Philippine government had publicly recognized emigration as an essential part of economic development ${ }^{[28]}$. This shift was reinforced by a discourse of neoliberal education, where educational purpose became mostly about providing student consumers with the best means to access lucrative opportunities in the job market. As such, colleges and universities were institutions that would enhance human capital for national development and 'export' to other countries. Private institutions willingly took on this new role in the nation's labor export strategies, eager to offer majors that would be popular among aspiring migrants.

Furthermore, the track-based, technicalized curriculum for the two-year senior high school (Grades 11 at 12) in the Philippines is focused on mostly foreign capitalist firms and their local partners' specific needs. A comprehensive analysis of the needs of developed countries/territories among the top 10 destinations of migrant Filipinos ${ }^{[30]}$ vis-a-vis the proposed technicalvocational-livelihood (TVL) tracks or courses in Philippine senior high school proves that countries such as the US, Saudi Arabia, Canada, United Arab Emirates, Australia, Malaysia, Japan, UK, Hong Kong, and Singapore will benefit from the existing neoliberal restructuring of Philippine education. Several courses in 
the country's senior high school program [17]_ such as Household Services , Housekeeping, Slaughtering Operation, Welding, Food and Beverage Services, and Caregiving are outrageously suitable only to overseas jobs, and beneficial only to overseas businesses-such as Medical Transcription and Contact Center Services, to name just a few examples.

The Philippine $\mathrm{K}$ to 12 program's labor exportorientation has been evident since its inception and is continuously reiterated as a policy ${ }^{[31]}$.

Former President Aquino ${ }^{[32]}{ }^{[33]}$ in two speeches both given in 2015, raised concerns that the qualifications of Philippine graduates would no longer be accepted abroad and therefore apparently affect their foreign employment prospects, asserting in his last State of the Nation Address that some OFWs have been demoted because of the country's old non-K to 12 system. Oddly, even before implementing the $\mathrm{K}$ to 12 scheme in the Philippines, Southeast Asia's biggest remittance receiver, is second only to China in the Asia-Pacific region ${ }^{[34]}$. It must be noted that each country in Asia is by now $\mathrm{K}$ to 12 compliant. Thus, based on the Philippine government's persistent declaration that $\mathrm{K}$ to 12 and labor export complement each other, the country's economy will be more be dependent on remittances from OFWs once this educational restructuring is fully implemented.

\section{Displaced Workforce}

The realization of the $\mathrm{K}$ to 12 programs has relentlessly affected the workforce in higher education. One of the negative consequences of the restructured educational system is the displacement of around 25,000 ${ }^{[31]}$ to $80,000^{[35]}$ professors and non-teaching personnel in private and public colleges and universities. The $\mathrm{K}$ to 12 scheme has reduced the faculty members' teaching workloads from 51-63 units to only 36 companies for general education subjects, similar to that of neoliberal Anglo-American schemes of de-emphasizing the so-called "war against the humanities" [36].

According to the government, displaced professors and non-teaching personnel can transfer to the senior high school [32]. However, the transition process or the swapping of teaching levels might not be as smooth as what it seems to be. Formerly tenured professors have to go through arduous application processes to start from scratch as provisional (part-time or contractual) entry-level senior high school teachers. The unreasonable reduction of income and instant increase of workloads of many college/university professors, who will involuntarily transfer to public senior high schools, are anti-labor.

For instance, in the National Capital Region, as per the government's data ${ }^{[35]}$, the mean income of full- time faculty in state-financed higher education institutions, local government-financed universities and colleges, private non-sectarian, and private, sectarian tertiary level institutions are as follows: 36,168 pesos; 29,475 pesos; 21,062 pesos; and 40,955 pesos. Such mean wage rates are higher than the entry-level pay for the Teacher II rankthat will be granted to professors who will transfer to public senior high schools — which is just 19,940 pesos. Furthermore, it must be emphasized that NCR tertiary level institutions' workloads are relatively lighter than workloads in public elementary and high schools. For example, teachers' full teaching load in some NCR colleges and universities is only $12-18$ hours per week. In contrast, in public elementary and high schools, the maximum instruction load is 30 hours every week. Simply put, teachers are told to acknowledge pay cuts AND work harder.

In March 2015, a case was filed in the Philippine Supreme Court, testing the constitutionality of the K to 12 Law, pointing out that schools have beentilizing the system to require education sector workers to accept early retirement schemes, while at the same time promising them that they can be rehired soon as contractual workers ${ }^{[37]}$. In a separate Supreme Court appeal to stop the K to 12 Program filed on May 2015, petitioners revealed that in the University of Santo Tomas (UST) - one of the most prominent universities in the country-contracts for fulltime "fixed-term" faculty members openly state that they will not be re-employed come 2016 because of the $\mathrm{K}$ to 12 programs ${ }^{[38]}$. A number of these faculty members could have become regular employees by 2016 as they have served for at least three school years. Still, they were not be considered probationary workers because of the anticipated impact of $\mathrm{K}$ to 12 . The same appeal reveals that some schools, such as Saint Louis University (SLU) one of the most prominent universities in Northern Philippines - have released documents detailing "projections for faculty requirements" in relation with $\mathrm{K}$ to 12, entailing that even full-time teaching staff will be displaced as early as the second semester of School Year 2016- 2017, with more displacements predicted for School Year 2017-2018. The adjunctivization of both teaching and non-teaching employees in universities will further weaken the Philippines' already anemic education sector unionism.

\section{Quality Management Mechanisms}

\section{A. Evaluating Organizational Performance through Accreditation}

The Philippine government has initiated Quality assurance and accreditation processes for higher education institutions to be globally competitive. Most colleges and universities have remarkably focused on quality assurance 
and Accreditation to examine whether the educational delivery system and the program meet the specified standard of academic quality. This has provided the strategic direction to stretch their full potential in ensuring that they considerably attain their educational goals and are generally equal in quality to comparable institutions, both local and abroad. It is the declared policy of the Commission on Higher Education to support and value the significant role of higher education institutions, the academic community, and other stakeholders in establishing a quality assurance system for the higher education sector. Institutional monitoring and evaluation for quality assurance are deemed complementary to accreditation ${ }^{[39]}$.

Higher education institutions (HEIs) play an essential role in preparing a country to be internationally spirited through the skilled human capital resources it produces. The task is intimidating as the institution has to continually check itself against the standards in place and keep itself abreast of the labor market's latest demands. This includes investing in a considerable amount of resources to develop its faculty, research, and facilities. Hence, clear evidence of the government's movement towards neoliberalism.

With the rising number of HEIs in the country and the demand for capable workers in the international marketplace, there is an urgent need to enhance education quality further. Accreditation is one way that HEIs keep themselves in check with the standards.

The external quality monitoring of HEIs includes Accreditation, audit, assessment, evaluation, and validation. Numerous issues have been identified, which are categorized under the areas of finance, frameworks, and flexibility. Moreover, rapid changes in the environment mean that an external quality monitoring agency should be maximally flexible, cost-effective, and minimally intrusive ${ }^{[40]}$. Institutional reviews are carried out by the process of extended peer review, a person or group with similar knowledge skills, experience, and status in the relevant context. For external quality review, peer reviewers are usually senior people with broad expertise in universities internationally and locally or persons with substantial knowledge in some aspects of quality assurance relevant to higher education. Peer reviewers bring their professional judgment to bear on the institution being reviewed. To ensure an effective, rigorous, fair, and transparent process, all parties must exhibit professional conduct and integrity throughout the quality review process ${ }^{[41]}$.

Before Kalinga State University (the university where we are currently employed) became a University, it went through severe scrutiny and thorough planning to attain total transformation required by the Commission on Higher Education. From a lowly community college in 1974, the Kalinga-Apayao State College has successfully developed into a state university offering different programs in information technology, education, entrepreneurship, agriculture, forestry, engineering, criminology, tourism, and arts and sciences, propelling itself as a premier higher education institution in the province of Kalinga. A critical factor in the state university's success has been its aggressive accreditation efforts.

\section{$\underline{\text { B. Individual Performance through Faculty Evaluation }}$}

Teacher autonomy and commitment are central to establishing motivating educational experiences that foster the development of creativity and critical thinking. Nonetheless, within current schooling systems, the types of academic backgrounds, as envisaged by Eisner and Greene, are susceptible to existing as rhetorical alone. The cultural meaning of schooling has radically changed and is now more explicitly geared to performance, results, and efficiency ${ }^{[42]}$. It appears that performativity has emerged as a dominant goalpost in modern schooling, often at the cost of more critical educational encounters. In performativity cultures, value, as represented through grades, points, and quantifiable targets, holds the potential to supersede values ${ }^{[43]}$.

Quality is a language that embraces humanity's life goal to be worth living. The universal impact on this regard cannot be overemphasized as a human individual puts a premium to a better standard of living. He or she aspires to launch quality in his or her mundane tasks in the workplace. This international impact is very noble, but there are critical questions on its achievement ${ }^{[44]}$.

The circumstance in the Philippine education

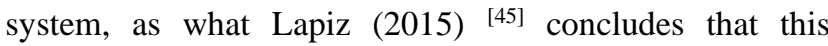
system is in the course of reconfiguration in responding to foreseeable global changes, just like the Philippine integration in the ASEAN and the challenges posed to more responsive curricula from primary education to higher education, using the Outcomes-based Education (OBE) structure. Importantly the great equalizer to life's enduring anxiety and demand in education. It is the topic of scholarly discussion to many specialists in the academe. As a great equalizer, it finds support in the hands of highly capable men and women in the academia whose professionalism is beyond reproach.

The teachers' performance is assessed in light of how their administrators percieve it on one hand and how the learners see it on the other hand. Along this line, the Philippine higher education insists on the vertical and 
lateral articulation of specialization of degrees from the undergraduate to the graduate level of knowledge to ensure the quality of higher education degree offerings through typology-based quality assurance and outcomes-based ${ }^{[46]}$. In the modified policies and standards for Teacher Education, as stated in CHED Memorandum 52, s. 2007, the faculty members teaching in teacher education programs must be a master's degree holder in education or an allied discipline.

Nonetheless, the drive towards a culture of standards, assessments, and accountability in education has had a "devastating" impact on many teachers and students [47]. Indeed, the emphasis on a performance-orientated, managerially effective teaching model has caused many teachers to struggle to develop broader educational goals ${ }^{[48]}$. Dewey (1986) ${ }^{[49]}$ argued that imposing an alleged uniform method for everyone breeds mediocrity in all but the very exceptional. As a result, teachers often find their values challenged or displaced by the pervasive "terrors of performativity" [43].

Cognizant that standardization reduces the quality and quantity of what is taught and learned in schools ${ }^{[50]}$, teachers are faced with the dilemma of conformity or rebellion in praxis. For many teachers, submission to school culture prevails to support pupils in achieving the ever-increasing targets set in national testing regimes ${ }^{[51]}$. Yet, it is to be acknowledged that "if you create a culture of schooling in which a narrow means/ends orientation is promoted, that culture can undermine the development of intellectual dispositions." Teacher acquiescence to neoliberal agendas can therefore be seen to exist at the expense of meaningful pupil engagement and development.

\section{CONCLUSION}

\section{The K to 12 Program}

Karl Marx's idea on structure-superstructure contends that education is thought to serve as an instrument in reproducing society's class structure, thus producing the dominant class's privileges. In the Philippines, education has also been used to advance neoliberalism, where significant changes are made by implementing the $\mathrm{K}$ to 12 programs, consequently modifying the curriculum, displacing the workforce, and emphasizing technical skills development. Intensifying quality education campaigns in HEIs thru Accreditation are suited not to develop intellectuals but mostly to produce more skilled labor force needed in the dominating global capitalism.

A traditional intellectual inquiry has been replaced with stress on performativity, emphasizing skills where marketization becomes the new widespread shift commodifying teaching and learning. The interest of the neoliberalists has controlled the Education for All launched in 1990. The United Nations commitment as written in the Millennium Development Goal (MDG) which states that by 2015 , children will be able to finish a full course of basic schooling; however, this target is defective in a sense that it does not fully address the need for quality education in schools which is supposed to be the main goal in any educational institution.

Rather than ensuring universal primary education, neoliberal school reform focuses on the corporatization of higher education and re-gearing primary and secondary schools to supply global capitalism's skilled labor needs. It pays lip service to education as a general right, but its center does not deliver education as a community service but as a profitable commodity. Commercialized education has been long a coping mechanism for many poor counties, but neoliberal school reforms from the $1980 \mathrm{~s}$ beyond have made commercialization far worse.

Thus, instead of undergoing intensive and comprehensive primary education, students are now expected to prepare themselves as mere commodities, simple workers (maids, caregivers, cleaners, waiters, and carpenters of the world) - clear evidence of advancing neoliberalism through education.

For Sison (2015) ${ }^{[12]}$, following the US's dictates in education will not solve the country's unemployment. This must be taken down to its roots from its fundamental problems of the Philippines' underdevelopment, absence of industrialization and land reform, and only by a collective effort of the people to transform the Philippines into a country for the masses for the few elites.

\section{Quality Assurance Mechanisms}

\section{A. Organizational Performance}

The government's current thrust to effect economic and social changes in Filipinos' lives is apparent in the paradigm shift and transformation in the Philippine educational system. This was envisioned for higher education institutions to produce highly competent and competitive graduates at par with the graduates of international Higher Education Institutions (HEIs) through quality education recognized here and abroad. With the Philippines' current plan to join the Southeast Asian nations for an open trade for capable graduates, the Commission on Higher Education (CHED) sets stricter qualification standards measured through a minimum set of criteria evaluated by accrediting agencies.

Thus, quality is the core of any business model to 
gain status and reliability from the local and international community. Acknowledgment from various accrediting and certifying bodies and agencies provides a better opportunity for the organizations to establish their worth and claim of quality. For Higher Education Institutions, internationalization is the name of the game to get keep their fire ablaze and to take the lead in offering great worth to society. High cost, huge size, diversity, and globalization are forces that have combined to draw attention to tertiary education quality and the need for formal quality assurance systems ${ }^{[52]}$.

The indication of academic performance evaluation in state universities and colleges has been a constant practice in the Philippines. Performance is completing a known job and undertaking that is evaluated and measured against pre-set known standards of correctness, exactness, completeness, speed, and efficiency. These are the results of an individual's activities, an organization, or even an investment over a given period. According to Sampson, Driscoll, Foulk, and Carroll (2010) [53], the performance and success of a faculty member of a university are based on how they perceive and how knowledgeable they are to the different primary and fundamentals of teaching, research and service in such a way that it uses the available resources. Faculty members are also expected to contribute substantially to the learning of their students and their growth academically.

Any Quality Assurance system, either locally or internationally recognized, used and adopted by the HEIs, must reflect on the quality of their graduates, which is one way of determining an institution's performance. Achieving excellence is a never-ending process of improving the quality of products and services, bounded by measures of the unobtainable goal of perfection.

\section{B. Faculty Performance}

Quantifying one's capability to promote excellence is an enduring process to meet certain evaluation standards wherein a specific level of quality is determined to provide vital information for the intentional community and global market.

The activities of 'performativity' are apparent in teachers' day-to-day activities and the social relations between teachers. Teachers are required to choose and judge their actions. Others judge these actions in turn based on their contribution to organizational performance. There is a change in focus from a concern with individual needs to aggregate accounts ${ }^{[54]}$. This is synonymous with the underlying philosophy prevalent in corporate managerialism. Thus, schools in the context of the market have shifted their organizational emphasis and focus on performance.

Similar to our academic experiences, we are given mandatory requirements to accomplish before the school year ends. The level of attainment of these requirements determines the result of our performance evaluation. Aside from Instruction, supposedly the primary coverage of the job description, HEI faculty members are obliged to conduct research, create instructional innovations, and provide community services. Consequently, teachers tend to sacrifice their instructional responsibilities to comply with the other obligations they have to fulfill. In my experience, I have to get myself absent for a few days to attend community service obligations to our adopted barangays. Likewise, conducting research requires going to places in gathering information. Otherwise, no output would mean no points added- no chance of getting promoted. Furthermore, it would also mean no performance bonus for my college/department due to failure to meet the required quota of researches per department.

The new managers must now evaluate the worth of individual teachers' contributions and outputs and judge if they are of value to the school's overall visibility. The new managers must now assign a grade to each individual teacher relative to another based on his or her performance in that year of appraisal and, with that grade, the performance monetary incentives. Ravitch (2013) points out how such incentives could possibly promote rivalry, discourage teamwork, lower overall morale, create dissension and resentment, and lead teachers to focus on themselves and short-term gains. Murnane and Cohen (1986), in their comprehensive survey of the history of "merit pay," found that merit pay "dramatically increases the tensions surrounding the formal evaluation process" (p. 18), leading to a recalibration of formerly collegial relations.

On the other hand, performance evaluation could serve as a motivation for self-improvement. The attracting benefits of promotion like a high salary, an appointment to higher ranks, social respect, and acceptance, are potent stimulants for teachers to attend professional development activities like seminars, training, and consortia and apply for international scholarships to enhance their knowledge and skills, thereby conforming to the quality standards set by the organization. Bandura (1989) ${ }^{[55]}$ defines selfefficacy as "the faith in one's own ability to mobilize the motivation, one's cognitive resources, and one's own ability to choose the right actions concerning the specific expectations."

As Ball (2003) points out, the neoliberal technologies of education - the market, managerialism, 
and performativity - are not merely tools to reform the state of the organizations but are also tools with which to reform the teacher, more specifically, the teacher's soul. In the performativity discourse, the teachers are "represented and encouraged to think about themselves as individuals who calculate about themselves, 'add value' to themselves, improve their productivity, strive for excellence" (Ball, 2003, p. 217).

\section{RECOMMENDATIONS}

Neoliberal reforms have also had debatably positive and negative impacts. Given the insightful effects of neoliberalism in shaping the 'conditions of possibility' for education, it is necessary for educators to understand its impacts and engage critically in its evolution.

1. It is nrecommended that educators need to fully understand neoliberalism and balance it with the nature of education as a social process of nurturing capacities for practice.This will enable them to strengthen socio-cultural values while developing globally competitive skills of learners. This will ensure the preservation of unique social communities and identities while enabling learners to function in an increasingly interconnected world.

2. The Department of Education and the Commission on Higher Education must thoroughly review performance standards that demand activities that "consume vast amounts of time and energy and reduce the time and energy which teachers can spend on genuine innovative teaching or a real focus on teaching and learning" (Turner-Bisset, 2007, p. 195). The intensified gathering of performative information takes a toll on teachers; as a result, they have less time and energy to make any improvement on their pedagogical practice (Ball, 2003, 2004).

3. Clarity about the purpose of performance appraisal is very much required. All too often, initiatives are adopted in good faith but come across as misguided and demeaning, constrained by political agendas and extant discourse. The development of systemic approaches is required; one that approximates best practice and seeks to build up a collaborative professional culture that facilitates the ongoing refinement of effective teaching is necessary.

\section{ACKNOWLEDGEMENTS}

I want to acknowledge the Kalinga State University for giving me the opportunity and sufficient support in order for me to be able to successfully conduct this research.

\section{REFERENCES}

[1] Furman, G. (Ed.). (, 2012). School as a community: From promise to practice. SUNY Press.

[2] Ozturk, I. (2001). The role of education in economic development: a theoretical perspective. University Library of Munich, Germany. ttps://papers.ssrn.com/sol3/papers.cfm?abstract_id=113754 1

[3] Baker, D., Cummings, E., \&Kintisch, B (2008). Pennsylvania's Best Investment: The Social and Economic Benefits of Public Education. https://www.eplc.org/wpcontent/uploads/2015/03/Socialand-Economic-Benefits-of-Education-08.pdf

[4] Lockheed, E. Marlaine, and Adriaan M. Verspoor. 1991. Improving Primary Education in Developing Countries. Washington, DC: Oxford University Press for the World Bank.

[5] Durban, J., and R. Catalan. (, 2012). Issues and Concerns of Philippine Education through the Years. Asian Journal of Social Sciences \& Humanities 1 (2): 61-69

[6] Reyes, V. (2010). The Philippine Department of Education: challenges of policy implementation amidst corruption. Asia Pacific Journal of Education, Vol. 30, No. 4, December 2010, 381-400.

[7] Carino, L., Iglesias, G., \& Mendoza, M.F. (1998). Initiatives are taken against corruption: The Philippine case. In Programme for Accountability and Transparency (Pact) of the Management Development and Governance Division (pp. 8-25). New York: United Nations Development Programme

[8] Pernia, R. A. (2017). The venture into higher education: exploring politics of education in a Philippine local government college. Philippine Political Science Journal, 38(2), 123-145.

[9] Smith, Adam, and Edwin Cannan. The Wealth of Nations. New York, N.Y: Bantam Classic, 2003. Print.

[10] Martinez, E., and Garcia, A. (1997). What is Neoliberalism?.CorpWatch Holding Corporations Accountable. https://corpwatch.org/article/whatneoliberalism

[11] Olssen, M., \& Peters, M. A. (2005). Neoliberalism, higher education, and the knowledge economy: From the free market to knowledge capitalism. Journal of education policy, 20(3), 313-345.

[12] Sison, J.M. (2015). APEC's Neoliberal Offensive and its Effect on the Philippine Education.https://josemariasison.org/apecs-neoliberaloffensive-and-its-

effectonphilippineeducation/?fbclid=IwAR1sNhks_myEZn mw39dskO0KSVOc0IsYzOUUsUDssOu7_Q358VPU74W tvWQ

[13] Tomasevski, K. 2001 Right to Education Primers No. 3: 
Human rights obligations: making education available, accessible, acceptable, and adaptable. NovumGrafiska AB, Gothenburg

[14] De Saxe, J. G., Bucknovitz, S., \& Mahoney-Mosedale, F. ( 2018) The Deprofessionalization of Educators: An Intersectional Analysis of Neoliberalism and Education "Reform." Volume: 52 issue: 1, page(s): 51-69 Article first published online: August 11, 2018; Issue published: January $1, \quad 2020$ https://doi.org/10.1177/0013124518786398

[15] Davies, B., and Bansel, P. (2007). Neoliberalism and Education. International Journal of Qualitative Studies in Education (QSE), v20 n3 p247-259 May 2007

[16] Department of Education [DepEd]. (2015b). K to 12 basic education program midterm report. Pasig: DepEd.

[17] Department of Education. (2015a). Technology and livelihood education (TLE) and technical-vocational livelihood (TVL) track. Retrieved from http://www. deped.gov.ph/k-to-12/curriculumguides/TechnicalVocational-Track

[18] San Juan College. (2013a). About SJC. Retrieved from http://www.sanjuancollege.edu/pages3533.asp

[19] Torrevillas, D. (2015, April 30). Philippine business bullish on $\mathrm{K}$ to 12 . Philippine Star. Retrieved from http://www. philstar.com/opinion/2015/04/30/1449479/philippinebusine ss-bullish-k-12

[20] Department of Education Regional Office VI. (, 2013). Education-and-the-structural-crisis-of-capital/

[21] Cruz, I. (2016, February 11). Business and K to 12. Philippine Star. Retrieved from http://www.philstar. com/education-and-home/2016/02/11/1551711/ businessand-k-12

[22] Stahl, R., \&Mulvad, A. (2015, August 4). What makes Scandinavia different? Jacobin. Retrieved from https:// www.jacobinmag.com/2015/08/national-reviewwilliamsonbernie-sanders-sweden/

[23] Constantino, R. (1970). The Miseducation of the Filipino. Journal of Contemporary Asia, 1(1). Retrieved from http://eaop.ucsd.edu/198/group-

identity/THE\%20MISEDUCATION\%20OF\%20THE\%20F ILIPINO.pdf

[24] Constantino, R. (1975). The Philippines: A past revisited (vol. I). Quezon City: R. Constantino.

[25] GimenezMaceda, T. (1993). The Filipino national language: Discourse on power. Retrieved from sealang. net/sala/archives/pdf8/maceda2003filipino.pdf

[26] Ordoñez, E. (Ed.). (, 1996). Nationalist literature: A centennial forum. Quezon City: University of the Philippines Press and PANULAT

[27] Cort, R. W. (Producer), \&Herek, S. (Director). (, 1995). Mr. Holland's Opus. [Motion picture]. USA: MetroGoldwyn-Mayer. Retrieved from https://www. youtube.com/watch?v=AsC2lkrfwlg

[28] Rodriguez, Robyn, M., 2010. Migrants for Export: How the Philippine State Brokers Labor to the World. Minneapolis, MN: University of Minnesota Press.

[29] Asia, Maruja M.B. 2006. "The Philippines' Culture of Migration." Migration Policy Institute. http://www.
migrationinformation.org/Profiles/display.cfm?ID=364

[30] Commission on Filipinos Overseas. (, 2009). Stock estimates of overseas Filipinos. Philippine Overseas Employment Administration (POEA). Retrieved from http://www.

poea.gov.ph/stats/Stock\%20Estmate\%202009.pdf

[31] Department of Education [DepEd]. (2015b). K to 12 basic education program midterm report. Pasig: DepEd.

[32] Aquino, B. S. (2015). Speech at the "K to 12, Kayangkaya, Sama-Sama!" celebration. Philippines: Official Gazette. Retrieved from http://www. gov.ph/2015/05/29/speechpresident-Aquino-at-the-K to-12-kayang-kaya-sama-samacelebration/

[33] Aquino, B. S. (2015b). State of the Nation address. Retrieved from http://www.gov.ph/2015/07/27/ presidentAquino-sixth-sona/

[34] World Bank. (2016). Migration and remittances factbook 2016. Washington, DC: Global Knowledge Partnership on Migration and Development (KNOMAD).

[35] Department of Education, Department of Labor and Employment \& the Technical Skills and Development Authority. (2015). Penultimate report of the interagency technical working group of the Department of Education, Department of Labor, and the Technical Skills and Development Authority.

[36] Nisen, M. (2013, June 26). America Is raising a generation of kids who can't think or write clearly. Business Insider. Retrieved from http://www.businessinsider. com/the-waragainst-humanities-2013-6

[37] Merueñas, M. (2015, March 24). SC seeks gov't side on plea vs. K-12. GMA News Online. Retrieved from http://www.gmanetwork.com/news/story/458070/ news/nation/sc-seeks-gov-t-side-on-plea-vs-k-12

[38] Tinio, A., Colmenares, N., Lumbera, B., Zarate, C., Hicap, F., Ilagan, L., Cruz, R. (2015). Petition for certiorari and prohibition (with a prayer for a temporary restraining order and write of preliminary injunction). Retrieved from https://www.academiaedu/12666794/Suspend_K_to_12_Al liance_Supreme_Court_Petition_to_Stop_K_to_12_RA_10 533

[39] Lagrada, H.D. Quality Assurance in Philippine Higher Education: The Case of IQUAME and Accreditation. Proceedings AACCUP 20th Annual National Conference, Manila, 2007.

[40] Billing, D. International Comparisons and Trends in External Quality Assurance of Higher Education: Communality or Diversity?, Higher Education, Vol. 47, 2004.

[41] Eaton, J. S. Accreditation and Recognition of Qualifications in Higher Education: the United States, Quality and Recognition in Higher Education, OECD, 2004.

[42] Brennan, J. and Shah, T. Quality Assessment and Institutional Change: Experiences from 14 Countries, Higher Education, Vol. 40, 2000.

[43] Hill, D. (2007). Critical teacher education, new labor, and the global project of neoliberal capital. Policy Futures in Education, 5(2), 204-225. 
[44] Ball, S. J. (2003). The teacher's soul and the terrors of performativity. Journal of Education Policy, 18(2), 215228.

[45] Villaganas, Victor D., Adora A. Villaganas, Mary Anne C. Villaganas, and Reynaldo B. Inocian. (2017). "Performance Appraisal To Ensure Quality Management System (Qms)." International Journal of Research - Granthaalayah, 5(5), 255-269. https://doi.org/10.5281/zenodo.583917.

[46] Lapiz, G. B. (2015). Faculty Qualifications Across The Vertically articulated Colleges Of Cebu Normal University; The Policy Framework. European Scientific Journal, Vol. 11 (16), 192-201.

[47] CHED MEMORANDUM ORDER NO. 46, S. (2012). Republic of the Philippines, Office of the President. Retrieved from Commission on Higher Education: http://pacu.org.ph/wp2/wpcontent/uploads/2013/03/CMONo.46-s2012.pdf

[48] Hursh, D. (2000). Neoliberalism and the control of teachers, students, and learning: The rise of standards, standardization, and accountability. Cultural Logic, 4(1), 41.

[49] McNess, E., Broadfoot, P., \& Osborn, M. (2003). Is the effective compromising the affective? British Educational Research Journal, 29(2), 243-257.

[50] Dewey, J. (1986). Mediocrity and individuality. Educational Forum, 50(3), 357-362.

[51] McNeil, L. (2009). Standardization, defensive teaching, and the problems of control. In A. Darder, M. Baltodano\& R. D. Torres (Eds.), The critical pedagogy reader (2nd ed), (pp. 384-396). New York, NY: Routledge

[52] Greene, M. (2005). Teaching in a moment of crisis: The spaces of imagination. New Educator, 1(2), 77-80.

[53] Roberts, V. (2001). Global Trends in Tertiary Education Quality Assurance Implications for the Anglophone Caribbean. Educational Management Administration \& Leadership, 29(4), 425-440.

[54] Sampson Jr, J. P., Driscoll, M. P., Foulk, D. F., \& Carroll, P. S. (2010). Successful faculty performance in teaching, research and original creative work, and service

[55] Ball, S. J. (2000). Performativities and Fabrications in the Education Economy: Towards the Performative Society? The Australian Educational Researcher, 27(2), Page 1.

[56] Bandura, A. (1997). Self-efficacy: The exercise of control. New York: Freeman.

[57] Reardon, M. (2013). A review of the literature on teaching evaluation. Richmond, VA: Metropolitan Educational Research Consortium and Virginia Commonwealth University

[58] Bernstein, B. (1996) Pedagogy Symbolic Control and Identity (London: Taylor \& Francis).

[59] Bernstein, B. (2000) Official knowledge and pedagogic identities: the politics of recontexualising, in S. J. Ball (ed.), The Sociology of Education: major themes (London: Routledge Falmer). 